\section{TEOLOGI MUHAMMADIYAH}

(Kasus Pernikahan dengan Ahli Kitab dan Kepemimpinan Wanita)

\section{Zuriatul Khairi}

Fakultas Psikologi UIN Suska Rian

\section{Abstract}

The Theology of Muhammadiyah : The Cases of Marriage With Ahl-Kitab and The Leadership of Woman: The plurality can not be separated from the religious understanding. The development of Islamic studies after the companion era has likely created the fragmentation of Islamic studies into some separated disciplines (Kalam, fiqh, tafsir, tasauf). This writing tries to analyze the relationship between the concept of Mubammadiyah's belief on its nash and fiqh about the marriage with ahl kitab and the leadership of woman. By studying the formal decisions of Mubammadiyah through historical approach, it is described the change of the concept of belief to nash to view how is the relationship between theology and fiqh.

Keywords: Theology Muhammadiyah, Abl Kitab, The Leadership of Woman.

\section{Pendahuluan}

Setelah masa Rasulullah saw, penyiaran ajaran Islam dilakukan oleh para shahabat, tabi'in, dan seterusnya. Islam juga disiarkan ke luar wilayah Arab, ke daerah yang memiliki kepercayaan dan kebiasaan yang berbeda. Kepercayaan yang semula bersumber dari nash, kemudian bercampur dengan akal kreatif yang beragam, lahirlah beragam teologi dalam Islam; Syi'ah, Khawarij, Murji'ah, Mu'tazilah, Ahlussunnah, Qadariyah, Jabariyah, Najjariyah, Musyabbihah, Salafiyah, Wahabiyah, Bahaiyah, Ahmadiyah, dan lain-lain. ${ }^{1}$ Lahirnya keragaman ini, telah terlihat sejak masa shahabat, khususnya dalam

${ }^{1}$ Lihat Abd. Aziz, Ahlussunah wal Jamaah: Dalam Bidang Aqidah dan Syariah (Pekalongan: Bahagia, 1990), hlm. 93-97.
Zuriatul Khairi, Teologi Mubammadiyah ...

cara memahami nash. Di Madinah, para ulama mengikuti contoh Ibnu 'Umar, membatasi diri mereka pada pengertian yang tegas (harfiah) dari Al-Quran dan Sunnah dengan menghindari interpretasi pribadi. Sedangkan di Kufah, para ulama mengikuti Ibnu Mas'ud dengan menggunakan pertimbangan nalar, analogi, dan tidak ragu-ragu dalam berspekulasi dan melakukan hipotesis problem dan situasi yang sebenarnya. $^{2}$

Teologi merupakan istilah yang berasal dari Barat, pada awalnya digunakan untuk menunjuk pada pembicaraan tentang tuhan, tetapi kemudian meluas menjadi kepercayaan atau paham keagamaan. Dari sinilah lahir istilah teologi ketuhanan, teologi pastoral, teologi Maria, teologi pembebasan, teologi pembangunan, sebagainya yang merupakan konsep spesifik dari teologi. Istilah lain dari konsep ini adalah Tauhid Sosial yang digunakan oleh Amin Rais. ${ }^{3}$ Dalam studi keislaman modern, Teologi (Akidah, Tauhid, Ilmu Kalam), selalu dipandang sebagai suatu disiplin yang berbeda dan terpisah dari Tafsir, Fikih dan Akhlak. Fikih yang dipandang sebagai ilmu mandiri, menurut Juhaya S. Praja, pada awalnya mencakup hukum-hukum Agama secara keseluruhan, baik hukum-hukum yang berkenaan dengan keyakinan ('aqa'id), maupun yang berkenaan dengan hukum-hukum praktis (amaliah) dan akhlak. ${ }^{4}$ Namun kemudian fikih digunakan sebagai istilah khusus bagi ahli-ahli hukum Islam untuk menunjuk kepada sekelompok hukum-hukum yang bersifat praktis, ${ }^{5}$ fikih dipandang sebagai suatu disiplin tersendiri.

Perbedaan paham keagamaan yang terjadi di tanah air (Muhammadiyah, NU, Persis, dll.), dipandang sebagai perbedaan fikih, bukan teologi atau akidah. Pandangan ini seolah-olah menyatakan

2 Tariq Ramadan, Teologi Dialog Islam-Barat: Pergumulan Muslim Eropa, terj. Abdullah Ali (Bandung: Mizan, 2002), hlm. 54.

${ }^{3}$ Menurut Amin Rais keyakinan kepada Tuhan tidak hanya dimanifestasikan pada keshalehan pribadi saja, tetapi juga diimplementasikan kedalam keadilan sosial. Untuk itu perlu doktrin teologi yang tegas moralitas. 12.

${ }^{4}$ Juhaya S. Praja, Filsafat Hukum Islam (Bandung: LPPM-UIB, 1995), hlm.

${ }^{5}$ Lihat ibid., hlm. 12-13. 
Al-Fikra: Jurnal Ilmiah Keislaman, Vol. 8, No. 2, Juli-Desember 2009

bahwa akidah mereka sama, hanya fikih mereka yang berbeda. Konsep ini tentu secara logis akan mengatakan akidah yang sama dapat melahirkan fikih yang berbeda, dan itu berarti tidak ada hubungan antara akidah dan fikih.

Benarkah fikih tidak berhubungan dengan teologi? Tulisan ini akan menganalisa bagaimana hubungan antara teologi dengan fikih dalam kasus fikih pernikahan dengan ahli kitab dan kepemimpinan wanita dalam bahasan Muhammadiyah.

\section{Sumber teologi Muhammadiyah}

Dalam anggaran dasar yang pertama ketika Muhammadiyah didirikan tidaklah disebutkan bagaimana kepercayaan yang akan disebar luaskan oleh muhammadiyah, di dalamnya hanya disebutkan tujuan organisasi sebagai tertuang di dalam Statuten Moehammadijab 1912 pada artikel 2 adalah untuk menyebarkan pengajaran agama Nabi Muhammad saw kepada penduduk Bumiputra di dalam Hindia Belanda dan memajukan hal Agama kepada anggota-anggotanya. Tidak ditemukan penjelasan mengapa KH. Ahmad Dahlan menyebut pengajaran agama Nabi Muhammad saw dalam statuten ini, dan bukan menyebarkan pengajaran agama Islam. Tentu ada maksud penggunaan istilah tersebut, mungkin menyesuaikan dengan nama organisasi, atau karena rancunya pengajaran agama Islam pada masa itu. ${ }^{6}$ Dan kemungkinan pula karena keinginannya menyiarkan ajaran yang murni berasal dari Nabi Muhammad saw seperti apa yang KH. Ahmad Dahlan serukan agar untuk memimpin kehidupan seharusnya mempergunakan satu metode kepemimpinan yaitu Al Quran. ${ }^{7}$

Sepeninggal KH. Ahmad Dahlan, muncul upaya penyusunan konsep ajaran Islam yang akan dijadikan pedoman kehidupan beragama warga Muhammadiyah. Salah satu masalah yang dipandang

${ }^{6}$ Sebagaimana diketahui bahwa telah ada beragam paham ajaran Islam pada masa itu, khususnya Islam yang berkembang di Yogya dan Jawa.

KH. Ahmad Dahlan, dalam Abdul Munir Mulkhan, Pemikiran K.H. Ahmad Dablan dan Mubammadiyah Dalam Perspektif perubahan Sosial (Jakarta: Bumi Aksara, 1990), hlm. 223.
Zuriatul Khairi, Teologi Mubammadiyah ...

sangat penting adalah masalah rukun iman, yang dibahas pada mukhtamar tarjih pertama tahun 1929. Mukhtamar ini memutuskan beberapa masalah, di antaranya masalah rukun iman yang di dalamnya terdapat masalah iman kepada kitab-kitab. Al Quran merupakan Kitab yang mendapat perhatian utama dalam mukhtamar ini. Pembahasan terfokus pada bagaimana iman kepada Al Quran tersebut. Keputusan mukhtamar memperlihatkan betapa Muhammadiyah sangat meyakini tekstual Al Quran dan membatasi fungsi akal. Keputusan tersebut secara lengkap sebagai berikut:

"Kita wajib percaya akan hal yang dibawa oleh Nabi s.a.w. yakni Al-Quran dan berita dari Nabi s.a.w. yang mutawatir dan yang memenuhi syarat-syaratnya. Dan yang wajib kita percayai hanyalah yang tegas-tegas saja, dengan tak boleh menambahnambah keterangan yang sudah tegas-tegas itu dengan keterangan berdasarkan pertimbangan (perkiraan), karena firman Allah: "Sesungguhnya persangkaan itu tidak sedikitpun berguna untuk mencapai kebenaran”.(Surat Yunus: 36).

Adapun syarat yang benar tentang kepercayaan, dalam hal ini ialah jangan ada sesuatu yang mengurangi Keagungan dan Keluhuran Tuhan, dengan mempersamakan-Nya dengan makhluk. Sehingga andai kata terdapat kalimat-kalimat yang kesan pertama mengarah kepada arti yang demikian, meskipun berdasarkan berita yang mutawatir (meyakinkan), maka wajiblah orang mengabaikan makna yang tersurat dan menyerahkan tafsir artinya kepada Allah dengan kepercayaan bahwa yang terkesan pertama pada pikiran bukanlah yang dimaksudkan, atau dengan takwil yang berdasarkan alasan-alasan yang dapat diterima.",

Kelihatannya masalah dasar sumber keyakinan ini berkembang menjadi polemik, sehingga pada tahun 1935 PB Muhammadiyah mengirimkan edaran kepada cabang-cabang untuk mengirimkan masukan tentang masalah lima yaitu masalah apa itu agama, dunia, ibadah, sabilillah, dan qiyas. Masalah ini kemudian dibahas dalam

8 PP. Muhammadiyah, Himpunan Putusan Majelis Tarjih, hlm. 15-16. 
Al-Fikra: Jurnal Ilmiah Keislaman, Vol. 8, No. 2, Juli-Desember 2009

Tarjih khusus pada tanggal 29 Desember 1954 sampai tanggal 3 Januari 1955, yang memutuskan :

a. Bahwa DASAR muthlaq untuk berhukum dalam agama Islam adalah Al Quran dan Al Hadis.

b. Bahwa di mana perlu dalam menghadapi soal-soal yang telah terjadi dan sangat dihajatkan untuk diamalkannya, mengenai hal-hal yang tidak bersangkutan dengan ibadah mahdhah padahal untuk alasan atasnya tiada terdapat nash sharih di dalam Al Quran atau Sunnah shahihah, maka dipergunakanlah alasan dengan jalan Ijtihad dan Istinbath dari pada Nash-nash yang ada, melalui persamaan 'illat; sebagaimana telah dilakukan oleh 'ulama-'ulama Salaf dan Khalaf. ${ }^{9}$

Dari keputusan Majelis Tarjih ini terlihat bahwa Muhammadiyah sangat menyakini akan kebenaran nash sebagai sumber agama. Hal ini sangat jelas karena sebelum keputusan di atas, majelis menyebutkan bahwa "agama Islam adalah apa yang diturunkan Allah di dalam Quran dan yang tersebut dalam Sunnah yang shahih, berupa perintahperintah dan larangan-larangan serta petunjuk untuk kebaikan manusia di dunia dan Akhirat."10 Pernyataan ini menunjukkan bahwa Muhammadiyah menerima nash Al Quran dan Al Hadis shahih sebagai sumber kepercayaan agamanya. Sebagaimana disebutkan oleh Asjmuni Abdurrahman bahwa sumber pokok Agama Islam menurut Muhammadiyah adalah al Quran dan al Sunnah. ${ }^{11}$ Meskipun adanya pengakuan terhadap qiyas sebagai metode ijtihad dan istinbath, namun bukanlah sebagai dasar pokok bagi kepercayaan mereka. Dengan menempatkan Al Quran dan al Sunnah sebagai sumber pokok, berart pula penggunaan akal menjadi sekunder, yaitu apabila ada masalah yang tidak ditemui teks nashnya. Jika digambarkan secara diagram, kepercayaan Muhammadiyah terlihat sebagai gambar berikut:

${ }^{9}$ Ibid., hlm. 278.

${ }^{10}$ Ibid., hlm. 276.

11 Asjmuni Abdurrahman, Manhaj Tarjih Muhammadiyah metodologi dan Aplikasi (Yogyakarta: Pustaka Pelajar, 2004), hlm. 97 - 98.
Zuriatul Khairi, Teologi Muhammadiyah ...

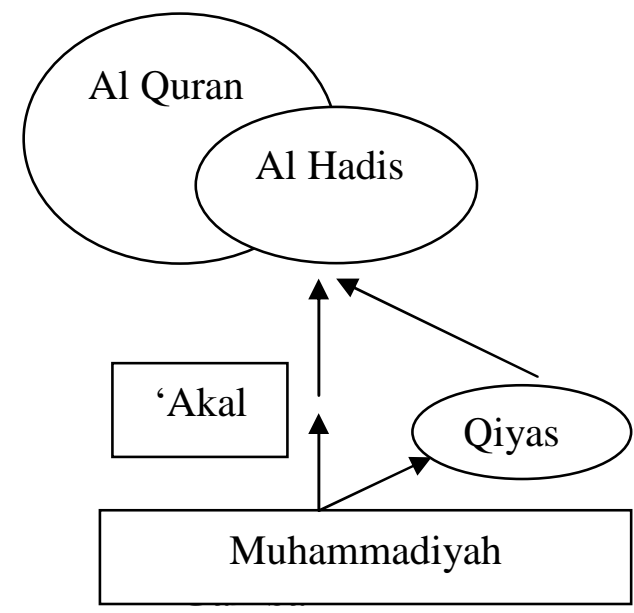

Gambar 1

Skema teologi Muhammadiyah pada masa awal

Bagi Muhammadiyah peran akal adalah untuk memahami teks wahyu, bukan menginterpretasikan wahyu, oleh karena itu apa yang disebutkan teks secara jelas itulah yang harus diikuti. Qiyas hanyalah untuk hal-hal yang belum diatur oleh nash. Abdul Munir Mulkhan menyebutkan bahwa Muhammadiyah memandang akal dapat dijadikan sebagai sumber hukum, namum ia tidak dapat berdiri sendiri. ${ }^{12}$ Penggunaan akal kerikat kepada nash, yaitu melalui qiyas.

Dalam perkembangannya ketika menghadapi berbagai masalah kontemporer, seperti keluarga berencana, bunga bank, dan perkawinan antar pemeluk agama, Muhammadiyah kemudian tidak hanya menggunakan qiyas tetapi juga menggunakan kaidah-kaidah ushul fiqhiyah dalam menetapkan hukumnya. ${ }^{13}$ Ini berarti Muhammadiyah

${ }^{12}$ Lihat Abdul Munir Mulkhan, Masalah-masalah Teologi dan Fiqh dalam Tarjih Mubammadiyah (Yogyakarta: Roykhan, 2005), hlm. 26.

13 Lihat Fathurrahman Djamil, Metode Ijtihad Majelis Tarjih Mubammadiyah (Jakarta: Logos, 1995), hlm. 70-148. 
Al-Fikra: Jurnal Ilmiah Keislaman, Vol. 8, No. 2, Juli-Desember 2009 mulai meyakini metode yang digunakan oleh para ulama fikih sebagai suatu kebenaran.

Dengan melihat perkembangan ini tampak bahwa terjadi pergeseran keyakinan Muhammadiyah terhadap metode yang digunakan oleh para ulama fikih.

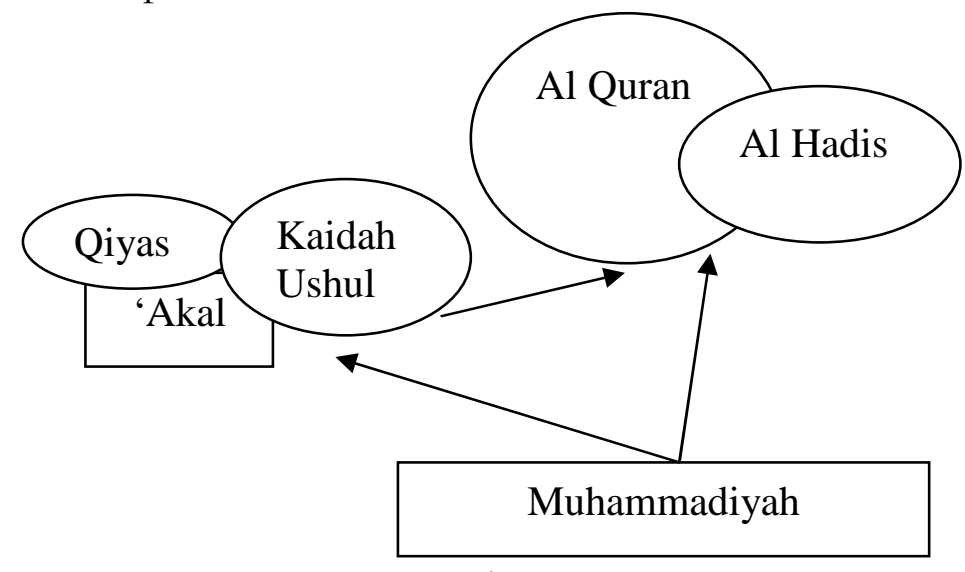

Gambar 2

Skema teologi Muhammadiyah kontemporer

Sebuah kaidah yang digunakan secara berani adalah ketika menetapkan hukum perkawinan antar pemeluk agama. Ushul yang digunakan dalam penetapan hukum ini adalah saddu al-drari'at. Dengan dasar ini, Muhammadiyah melarang perkawinan dengan ablul kitab yang secara tegas dibolehkan Al Quran.

\section{Fikih Pernikahan dengan Ahli Kitab}

Meskipun salah satu pendorong didirikan Muhamadiyah adalah sebagai upaya menahan lajunya kristenisasi yang dilakukan misionaris Belanda, namun tidak menyebabkan Muhammadiyah berbenturan dengan misionaris. K. H Ahmad Dahlan pendiri Muhammadiyah dikenal sebagai tokoh yang toleran dan sering melakukan dialog dengan misionaris. ${ }^{14}$

${ }^{14} \mathrm{Ibid}$., hlm. 48-49 tentang toleransi dan pluralitas.
Zuriatul Khairi, Teologi Muhammadivah ...

Bagi Muhammadivah masalah hubungan dengan non-muslim tidaklah menjadi hal yang terlalu urgen untuk dibahas, ini setidaknya hingga pertengahan tahun 1980 an. Setelah masa tersebut barulah muncul masalah ini, sebagaimana dimuat dalam Tanya Jawab Agama jilid 1.15 Terdapat tujuh masalah tentang hubungan dengan nonmuslim, yaitu; bergaul dengan non-muslim, makanan, donor darah dan perkawinan, menjawab salam non-muslim, tamu non-muslim, doa kepada orang tua non-muslim, warisan (orang tua) non-muslim, dan melayat jenazah non-muslim, serta satu masalah tentang pengangkatan guru non-muslim pada lembaga pendidikan Muhammadiyah.

Pada era reformasi, masalah hubungan dengan non-muslim ini kelihatannya merupakan sesuatu yang dipandang urgen oleh Muhammadiyah, sehingga Majelis Tarjih dan Pengembangan Pemikiran Islam (MTPPI) perlu membahasnya secara seksama, sehingga melahirkan sebuah buku yang berjudul Tafsir Tematik Al Quran: Tentang Hubungan Sosial Antarumat Beragama. ${ }^{16}$

Bagian kedua dari bab pertama itu memberikan apresiasi bahwa dasar hubungan antar umat beragama adalah dasar perdamaian. ${ }^{17}$ Sedangkan bagian ketiganya menyatakan bahwa Islam berasaskan keadilan terhadap semua manusia, dan prinsip cabangnya adalah

15 Buku ini merupakan kumpulan Tanya jawab agama yang telah dimuat di dalam "Suara Muhammadiyah" sejak tahun 1986 dan diterbitkan pada tahun 1990. Diperkirakan ini merupakan pemikiran pada akhir masa sebelum diberlakukannya asas tunggal dan awal diberlakukannya asas tunggal.

16 Meskipun buku ini di dalam pengantarnya disebutkan oleh Majelis Tarjih dan Pengembangan Pemikiran Islam (MTPPI) yang menyusunnya sebaga "wacana" namum menurut hemat penulis ini merupakan hasil pemikiran majelis yang sangat mencerminkan pemikiran para pemikir Muhammadiyah umumnya karena telah dibahas dalam pembahasan forum Munas Tarjih ke 24 di Malang tanggal 29-31 Januari 2000 sebagaimana dikemukan pada pengantar MTPPI. Buku ini membahas prinsip-prinsip hubungan antar umat beragama, hubungan baik dan kerjasama antar umat beragama, deskripsi Al Quran tentang ahli kitab, dan perkawinan beda agama dalam Al Quran

${ }^{17}$ Lihat ibid., hlm. $33-51$. 
Al-Fikra: Jurnal Ilmiah Keislaman, Vol. 8, No. 2, Juli-Desember 2009

perlakuan yang sama. Keadilan adalah asas yang berlaku untuk semua level, baik individu maupun kelompok. ${ }^{18}$

1. Konsep ahlul kitab

Hubungan antar agama bagi umat Islam secara umum adalah hubungan antara muslim dengan non-muslim, namun dalam bahasan agama lebih mengacu kepada konsep ahlul kitab, musyrik dan kafir. Ahlul kitab terdiri dari dua kata yaitu abl yang berarti yang memiliki dan kitab yang berarti kitab suci, maka ahlul kitab berarti orang yang mempunyai kitab suci. Di dalam Al Quran selain istilah ahlul kitab juga digunakan istilah 'allazîna utul kitâb' yang berarti orang-orang yang telah diberikan kepadanya kitab.

Konsep ahlul kitab dibahas secara khusus oleh MTPPI (Majelis Tarjih dan Pengembangan Pemikiran Islam). Setelah mengemukakan berbagai argumen pendapat mufassir baik klasik maupun moderen, majelis menyimpulkan bahwa ahli kitab itu terdiri dari Yahudi, Kristen, Majusi dan Sabiun, bahkan bisa diperluas sampai Konfusianis, Hindu, dan Buda. ${ }^{19}$ Kesimpulan ini berbeda dari apa yang dihasilkan Majelis Tarjih periode 1990-1995 yang dituangkan di dalam buku "Tanya Jawab Agama jilid 4" yang menyatakan:

Ahli kitab ialah penganut agama yang menjadikan Kitab Taurat dan Injil sebagai kitab suci mereka. Sedang Taurat dan Injil sekarang telah banyak masuk ke dalamnya perkataan-perkataan orang-orang yang hidup beberapa puluh tahun setelah Nabi Musa as dan Nabi Isa as meninggal dunia, sehingga tidak diketahui lagi mana yang merupakan firman Allah dan mana yang bukan. ${ }^{20}$

Dengan demikian terlihat perkembangan pendapat Muhammadiyah dalam konsep ahli kitab. Pendapat yang semula membatasi ahli kitab hanya pada pemeluk Yahudi dan Nasrani, diperluas kepada seluruh penganut agama lainnya.

${ }^{18}$ Lihat ibid., hlm. 51-57.

${ }^{19}$ Ibid., hlm. 151

20 Tim Majelis Tarjih Muhammadiyah, Tanya Jawab Agama, 4 (Yogyakarta: Suara Muhammadiyah, 2003), hlm. 206
Zuriatul Khairi, Teologi Mubammadiyah ...

Sementara itu, Tim Majelis tidak membedakan ahlul kitab dan non-muslim ketika menjawab pertanyaan tentang apakah boleh makan makanan non-muslim ?. Tim Majelis kelihatannya menyamakan ahlul kitab dan non-muslim dengan jawaban berikut: "Makanan-makanan ahli kitab (non-muslim) asal makanan itu termasuk yang halal, seperti nasi, daging sapi, bukan makanan yang haram seperti daging babi, halal dimakan." 21 Demikian pula tentang perkawinan dengan non-muslim, Tim Majelis menyebutkan : "Haram wanita muslim dinikahi pria nonmuslim, kalau wanita non-muslim nikah dengan Muslim, wajib dihindari." 22

AR. Fachruddin ketua PP Muhammadiyah 1971-1990, megemukakan konsep yang lebih tegas, menurutnya ahli kitab adalah orang Yahudi dan Nasrani termasuk orang Yahudi dan Nasrani yang ada sekarang dan berbeda dari konsep kafir, sebagaimana ungkapannya:

"Apa yang dimaksud dengan Ahli Kitab dalam berbagai ayat dalam Al Quran ialah kaum Yahudi dan Nasrani termasuk mereka yang sekarang tergolong dalam keduanya. Berbeda dengan orang Kafir, sembelihan Ahli Kitab halal dimakan muslim dan sebaliknya, demikian pula perkawinan antara laki-laki muslim dengan mereka."23

Ahmad Azhar Basyir ${ }^{24}$ juga menyatakan bahwa ahli kitab yang dimaksud Al Quran adalah kaum Yahudi dan Nasrani. ${ }^{25}$ Menurutnya surat al-Maidah ayat 5 mengajarkan bahwa makanan ahli kitab (sembelihan binatang halal oleh ahli kitab) halal dimakan oleh kaum Muslimin dan wanita kaum ahli kitab halal dinikah oleh kaum

${ }^{21}$ Tim Majelis Tarjih Muhammadiyah, Tanya Jawab, 1, hlm. 187.

22 Ibid.

23 Abdul Munir Mulkhan (penyusun), Jawaban Kiyai Mubammadiyah: Mengurai Jawaban Pak AR dan 274 Permasalahan dalam Islam (Yogyakarta: Kreasi Wacana, 2004), hlm. 177.

24 Ahmad Azhar Basyir adalah ketua PP Muhammadiyah priode tahun 19901995, dan sebagai ketua Majelis Tarjih pada masa AR Fachruddin.

25 Ahmad Azhar Basyir, Uswah Hasanah dalam Muhammadiyah (Yogyakarta: Suara Muhammadiyah, 1996), hlm. 59 
A1-Fikra: Jurnal Ilmiah Keislaman, Vol. 8, No. 2, Juli-Desember 2009

Muslimin. ${ }^{26}$ Pandangan ini sangat jelas memandang teks nash tersebut sebagai suatu yang jelas dan tidak perlu ditafsirkan.

Tim Majelis Tarjih di dalam Tanya Jawab Agama jilid 2, menyatakan bahwa: "ummat Yahudi dan Nasrani sekarang masih termasuk Ahli Kitab."27 Konsep ahlul kitab adalah orang Yahudi dan Nasrani ini juga dianut oleh Majelis Tarjih priode 1990-1995, seperti yang dapat dilihat pada buku Tanya Jawab Agama jilid 4, yang telah disebutkan di atas.

Dari perkembangan perkembangan konsep ahli kitab yang dibahas Muhammadiyah tersebut, terlihat bahwa Muhammadiyah sangat inten dalam memahami konsep ahli kitab. Jika direntang, terdapat tiga pemahaman, yaitu: pertama meragukan Yahudi dan Nasrani yang ada sekarang sebagai ahli kitab, kedua menyakini Yahudi dan Nasrani yang ada sekarang sebagai ahli kitab, dan ketiga memperluas makna ahli kitab kepada agama-agama yang lain.

2. Pernikahan beda agama

Dalam masalah perkawinan beda agama yang dibahas dalam bab empat "Tafsir Tematik" tersebut, majelis secara tegas melarang pernikahan dengan wanita musyrik meskipun tidak memberikan ketegasan tentang apakah ahli kitab atau Yahudi, Nasrani, atau bahkan penganut agama lainnya termasuk ke dalam kelompok musyrik. ${ }^{28}$ Pada bagian pernikahan dengan wanita ahlul kitab, Majelis seolah-olah apresiatif terhadap kebolehan pernikahan ini, sehingga perlu membahas persyaratan wanita ahlu kitab yang boleh dinikahi tersebut, namun setelah membahas perkawinan dengan pria non-muslim, Majelis mengubah apresiasinya dengan mengemukakan alasan larangan perkawinan beda agama. ${ }^{29}$ Alasan yang dikemukakan adalah kepentingan publik, sebagaimana diungkapkan:

${ }^{26}$ Ibid., hlm. 60

27 Tim Majelis Tarjih Muhammadiyah, Tanya Jawab, 2, hlm. 38.

${ }^{28}$ Lihat Majelis Tarjih dan Pengembangan Pemikiran Islam, Tafsir Tematik, hlm. 163-176.

${ }^{29}$ Lihat ibid., hlm. 176-220.
Zuriatul Khairi, Teologi Mubammadiyah ...

Perkawinan memang dilakukan oleh pribadi-pribadi, namun ia merupakan lembaga yang berkaitan dengan kepentingan publik. Karena itu pengaturannya tidak hanya semata-mata berdasarkan pertimbangan atau alasan agama saja, tetapi juga perlu mempertimbangkan kepentingan publik itu. Aturan pernikahan beda agama dalam Al Quran memang bisa dipahami seperti yang telah diuraikan secara panjang lebar di atas. Namun pelaksanaannya di Indonesia sekarang sudah barang tentu tidak bisa se liberal itu. Tidak semua kelompok umat di negeri ini telah berdaya untuk melakukan itu. Bila itu dilakukan kemungkinan bisa mengganggu kerukunan antar umat beragama yang selama ini telah diusahakan untuk dibina dengan baik. ${ }^{30}$

Pandangan ini sesuai dengan keputusan Muktamar Tarjih Muhammadiyah XXII tahun 1989, dan pendapat Majelis Fatwa Tarjih Muhammadiyah yang melarang perkawinan beda agama. ${ }^{31}$ Tentu saja pelarangan ini merupakan suatu kesimpulan yang berbeda dari harfiah nash.

\section{Fikih Kepemimpinan Wanita}

1. Wanita di bidang politik

Pada tahun 1976 Majelis Tarjih Muhammadiyah membahas tentang masalah perempuan dalam wilayah publik, pembahasan tersebut melahirkan pemikiran tematik "Adabul Mar'ah fil Islam" yang disahkan oleh majelis tarjih. Di antara keputusan adalah berkenaan dengan kewajiban wanita untuk terlibat dalam kegiatan politik praktis dan boleh atau tidak ada dalil yang kuat untuk melarang wanita menjadi pimpinan publik. ${ }^{32}$

${ }^{30}$ Ibid., hlm. 218-219.

31 Lihat ibid., hlm. 29. Lihat juga HPT Mubammadiyah (Malang: PD Muhammadiyah Kodya Malang, 1995), hlm. 301-308.

32 "Adabul Mar'ab fil Islam" memuat pada Bab VII Wanita Islam dalam Bidang Politik, dan Bab VIII Bolehkah Wanita Menjadi Hakim. 
Al-Fikra: Jurnal Ilmiah Keislaman, Vol. 8, No. 2, Juli-Desember 2009

Majelis Tarjih memutuskan bahwa para wanita diperlukan untuk terlibat dalam kegiatan politik, secara lengkap keputusan tersebut sebagai berikut:

"Kaum wanita Islam... diperlukan untuk ikut memikirkan soalsoal yang berhubungan dengan masalah ketatanegaraan dan ikut serta menggerakkan dan melakukannya, karena mengenai soal kemakmuran rakyat dan keamanan negara itu kaum wanita ikut bertanggung jawab." "33

Majelis mengelompokkan peran wanita dalam politik menjadi dua bagian; peranan yang langsung berupa praktik politik dalam badan-badan legislatif atau Dewan Perwakilan Rakyat dari pusat sampai daerah. Dalam hal ini kaum wanita harus ikut serta berjuang untuk mencapai jumlah perwakilan yang memadai; dan peranan tidak langsung, yaitu disalurkan dari rumah tangga, di tengah-tengah masyarakat dengan mengambil bagian aktif dan mengisi kesempatankesempatan bermanfaat di dalam masyarakat. Di dalam bidang tersebut kaum wanita harus dapat mengambil peranan yang menentukan. ${ }^{34}$

2 Wanita menjadi pemimpin

Dari aspek kepemimpinan, Majelis Tarjihpun memutuskan bahwa tidak ada alasan dalam agama untuk menghalang-halangi atau menolak perempuan menjadi hakim, direktur sekolah, direktur perusahaan, camat, lurah, walikota, menteri dan sebagainya. ${ }^{35}$ Perempuan harus ikut aktif dalam bidang politik, baik secara langsung ataupun tidak langsung. ${ }^{36}$ Wanita boleh saja menjadi hakim, direktur sekolah, direktur perusahaan, bahkan menjadi pemimpin masyarakat yang lebih luas seperti camat, walikota, menteri dan semisalnya.

33 Majelis Tarjih, Adabul Mar'ah fil Islam, dikutip oleh Syamsul Anwar, Kepemimpinan Perempuan dalam Islam, dalam Wawan Gunawan, dan Evie Shofia Inayati (ed), Wacana Figh Perempuan Dalam Perspektif Muhammadiyah (MTPPI PP Muhammadiyah Yogyakarta dan UHAMKA Jakarta, 2005), hlm. 49.

${ }^{34} \mathrm{Ibid}$.

35 Ibid.

36 Lihat Majelis Tarjih, Adabul Mar'ah fil Islam, hlm. 54-55.
Zuriatul Khairi, Teologi Muhammadiyah ...

Muhammadiyah berpendapat bahwa agama tidak memberi alasan bagi yang menolak atau menghalang-halangi. ${ }^{37}$

Dalam membuat keputusan tentang kebolehan tersebut, majelis terlebih dahulu mengemukakan empat dasar, yaitu:

(1) Amal shalih yang dilakukan oleh laki-laki dan wanita sama-sama mendapat balasan syurga dari Allah (surat An Nisa': 124).

(2) Kelebihan laki-laki dari wanita, surat An Nisa' ayat 34.

(3) Kenyataan ada wanita memiliki keistimewaan maknawi menyamai laki-laki. Dan ada hadis yang menerangkan: "Tak akan berhasil golongan orang yang menyerahkan kekuasaan urusan mereka pada seorang wanita".

(4) Jumhur Ulama berpendapat secara mutlak wanita tidak boleh memegang jabatan/memimpin di tengah-tengah kehidupan bermasyarakat. ${ }^{38}$

Dalam menelaah sumber di atas, majelis membolehkan wanita menjadi hakim dengan menafsirkan hadits tersebut, sebagaimana dimuat di dalam Adabul Mar'ah fil Islam:

Padahal seharusnya kita tafsirkan Hadits tersebut sebagai ungkapan sementara yang dikaitkan dengan gambaran tertentu pada masa tertentu yang pernah dialami umat manusia di masa jauh silam. Suatu keadaan yang sukar dicari persamaannya di masa kini. Dengan demikian pada zaman sekarang rasanya tak tepat lagi dipersoalkan: Bolehkah wanita menjadi Hakim ?39

Muhammadiyah berpendapat berbeda dari jumhur ulama, dengan melakukan penafsiran terhadap nash.

${ }^{37}$ Ibid., hlm. 57. selanjutnya disebut bahwa mengenai hadis Nabi saw. yang menyatakan : "Tak akan berhasil golongan orang yang menyerahkan kekuasaan urusan mereka pada seorang wanita." Harus ditafsirkan sebagai ungkapan sementara yang dikaitkan dengan gambaran tertentu dan bentuk yang pernah dialami umat manusia di masa jauh silam. Suatu keadaan yang sukar dicar persamaannya di masa kini. Dengan demikian pada zaman sekarang rasanya tak tepat lagi dipersoalkan : Bolehkah wanita menjadi hakim ?

${ }^{38}$ Lihat Majelis Tarjih, Adabul Mar ab fil Islam, hlm. 56-57.

39 Ibid., hlm. 57-58. 
Al-Fikra: Jurnal Ilmiah Keislaman, Vol. 8, No. 2, Juli-Desember 2009

\section{Hubungan Teologi dengan Fikih Muhammadiyah}

Kepercayaan pokok memiliki hubungan dengan kepercayaankepercayaan lainnya. Sebuah kepercayaan merupakan implikasi dan konsekuensi dari kepercayaan pokok. ${ }^{40}$ Oleh karena kepercayaan memiliki sumber, maka kepercayaan terhadap sumber suatu kepercayaan akan menentukan kepercayaan itu sendiri. Dalam Islam, Kepercayaan pokok disebut dengan rukun iman ${ }^{41}$ dan yang menjadi sumber kepercayaan adalah Al-Quran dan Hadis. Bagaimana kepercayaan terhadap Al-Quran dan Hadis akan menentukan terhadap ajaran agama yang diyakininya

Muhammadiyah mempercayai Al-Quran dan al Sunnah shahih sebagai sumber ajaran Islam, dan pemahaman agama (fikih) bersumber langsung dari keduanya. Sehingga apa yang dimaksud dengan agama Islam oleh Muham madiyah ialah apa yang diturunkan Allah di dalam Al-Quran dan yang tersebut dalam sunnah yang shahih, berupa perintah-perintah dan larangan-larangan serta petunjuk untuk kebaikan manusia Dunia dan Akhirat. ${ }^{42}$ Oleh karena itu juga diputuskan bahwa dasar muthlaq untuk berhukum dalam agama Islam adalah Al-Quran dan Al-Hadits. ${ }^{43}$ Penetapan batasan agama ini sangat penting untuk menghindari mengambangnya pengertian agama yang dapat menyebabkan menjadikan agama terhadap hal-hal yang sebenarnya tidak terdapat dalam ajaran Islam, dan memberikan batasan mana wilayah yang boleh berijtihad ${ }^{44}$

Dengan mendefinisikan agama Islam sebagai perintah-perintah dan larangan-larangan serta petunjuk untuk kebaikan manusia dunia dan akhirat yang terdapat di dalam Al-Quran dan Hadis shahih, yang menyebabkan mutlaknya berhukum berdasar Al-Quran dan Hadis, ini

40 Lihat Rokeach (1968) dikutip oleh Stuart Oskamp dan P. Wesley Schultz, Attitude and Opinions (New Jersey: Laurence Erlbaum Associates, 2005), hlm. 93.

41 Rukun iman terdiri dari iman kepada Allah, Malaikat, Rasul, Kitab, Hari Akhirat dan Qadla. Rukun iman ini divakini oleh Muhammadivah dan NU.

42 PP. Muhammadiyah, Himpunan Putusan, hlm. 276

43 Ibid., hlm. 278

${ }^{44}$ Lihat Asjmuni Abdurrahman, Manhaj Tariih Mubammadiyah, hlm. 23-27.
Zuriatul Khairi, Teologi Mubammadiyah ...

berarti Muhammadiyah telah membatasi wilayah ijtihad. Hal ini sesuai dengan hadis tentang pertanyaan Rasulullah saw. kepada Muadz bin Jabal yang berkenaan dengan cara memutuskan suatu perkara. ${ }^{45}$ Acuan pertama dalam memutuskan perkara adalah Al-Quran, jika tidak ditemukan di dalam Al-Quran, maka mencarinya pada sunnah Rasulullah, dan jika tidak diperoleh di dalam keduanya, maka di sinilah ijtihad berperan.

Agama Islam adalah ajaran perintah dan larangan berdasar kepada nash. Nash tidak boleh ditambah atau dikurangi, seperti yang penjelasan di dalam HPT:

"Kita wajib percaya akan hal yang dibawa oleh Nabi saw yakni Al

Quran dan berita dari Nabi saw yang mutawatir dan memenuhi syarat-syaratnya. Dan yang wajib kita percayai hanyalah yang tegas-tegas saja, dengan tak boleh menambah-nambah keterangan yang sudah tegas-tegas itu dengan keterangan berdasarkan pertimbangan (perkiraaan), karena firman Allah: “ sesungguhnya persangkaan itu tidak sedikitpun berguna untuk mencapai kebenaran".(surat Yunus: 36)."46

Penambahan ajaran agama (yang berhubungan dengan akidah dan ibadah) dari hal yang tidak bersumber pada nash, dipercayai sebagai bid'ah. Segala hal bid'ah dalam masalah akidah dan ibadah adalah sesat. Perubahan hanya dapat dilakukan dalam masalah mu'amalah. Dalam bidang ini pintu ijtihad terbuka lebar. ${ }^{47}$

Ijtihad dalam konsep Muhammadiyah yang dituangkan di dalam HPT adalah qiyas, yaitu ijtihad dan istinbath dari nash yang ada melalui

45 Di dalam Abu Daud, Sunan Abi Daud (Darul Fikri: Juz III), hlm. 303 terdapat hadis:

'An Anas min abli Hamash min ashấbi Muadz bin jabal inna Rasulallábi lammấ arada any yab'atsa Muadzan ila l Yamani qấla: kaifa taqdhiy idzấ 'aradha laka qadhấ ? qấla aqdhiy bikitabillâh. qấla: faillam tajid fiy kitấbillâh ? qấla: fabisunnati rasu lillấh. qấla: faillam tajid fiy sunnati rasu lilláh walấ fiy kitấbillấh ? qấla: ajtabidu ra'yiy walá alwu. Fadharaba rasulullấbi shadrabu, wa qấla: alhamdulillábi lammấ yardhấy rasulullấhi.

46 PP. Muhammadiyah, Himpunan Putusan, hlm. 15.

47 Lihat Achmad Jainuri, Idiologi Kaum Reformis, hlm. 86. 
Al-Fikra: Jurnal Ilmiah Keislaman, Vol. 8, No. 2, Juli-Desember 2009

persamaan 'illat. ${ }^{48}$ Pandangan ini merupakan hasil tarjih pada tahun 1955. Sebagaimana manhaj Majelis Tarjih dalam menetapakan keputusan, menerima ijtihad termasuk qiyas sebagai cara menetapkan hukum yang tidak ada nashnya secara langsung. ${ }^{49}$

Dalam perkembangan selanjutnya, mulai tahun 1968, kegiatan Muhammadiyah sudah mengarah kepada ijtihấd insyấ'i atau ijtihấd ibtidấi. 50 Sesuai dengan perkembangan sosial, budaya dan teknologi yang memunculkan masalah-masalah baru yang belum dibahas oleh para ulama terdahulu, maka ijtihad tarjih tidak dapat dilakukan. Karena dalam memutuskan masalah ini, perlu memperhatikan aspek yang baru muncul tersebut, sosial, budaya dan teknologi. Dalam pelaksanaannya masih tetap menggunakan kaidah ushul yang dikemukakan para ulama terdahulu: qiyas, istihbsấn, al mashlabat al mursalat, dan saddu al zariat.

Kepercayaan bahwa kaidah ushul fikih dapat digunakan untuk menginstimbathkan hukum, pada awalnya ditujukan terhadap masalah yang tidak ditemukan nash baginya, namun kemudian digunakan dalam konteks yang lebih umum. Kepercayaan kepada kaidah ushul mempengaruhi konsep teologi Muhammadiyah, hal ini dapat dilihat dari penggunaan kaidah ushul dalam masalah pernikahan dengan ahlul kitab.

Dalam menetapkan ketentuan pernikahan dengan wanita ahlul kitab, Muhammadiyah menggunakan kaidah saddu al zariat, yang membatalkan nash (Al-Quran surat al Maidah ayat 5) yang dipahami sebagai kebolehan menikahi muhshanất dari ahlul kitab. Menurut AR. Fachruddin, boleh laki-laki muslim mengawini perempuan ahli kitab,

48 Di dalam, HPT. hlm. 278. disebutkan:

"dalam menghadapi soal-soal yang telah terjadi dan sangat dihajatkan untuk diamalkannya, mengenai hal-hal yang tidak bersangkutan dengan ibadah mahdhah padahal untuk alasan atasnya tiada terdapat nash sharih di dalam Al-Quran atau Sunnah shahihah, maka dipergunakanlah alasan dengan jalan Ijtihad dan Istinbath dari pada Nash-nash yang ada, melalui persamaan 'illat; sebagaimana telah dilakukan oleh 'ulama-'ulama Salaf dan Khalaf'

49 Fathurrahman Djamil, Metode Ijtihad Majelis Tarjih Mubammadiyah (Jakarta: Logos, 1995), hlm. 161.

50 Ibid., hlm. 149.
Zuriatul Khairi, Teologi Mubammadiyah ...

meskipun ia memberikan catatan agar memperhatikan kemungkinan perpindahan agama si laki-laki kepada agama si perempuan, jika kemungkinan itu dikhawatirkan terjadi, maka perkawinan tidak dibolehkan. ${ }^{51}$ Anjuran untuk menghindari ataupun melarang pernikahan dengan wanita ahlul kitab tidaklah membatalkan kebolehan pernikahan tersebut. Larangan lebih ditujukan kepada laki-laki muslim yang diduga tidak mampu mempertahankan agamanya.

Hamka dalam memahami surat al Maidah ayat 5 yang menjadi dasar kebolehan laki-laki muslim menikahi ahlul kitab tersebut, mengemukakan bahwa konteks ayat tersebut adalah ditujukan kepada orang beriman, oleh karena itu menurutnya, laki-laki muslim yang boleh menikahi wanita ahlul kitab hanyalah laki-laki yang kuat imannya, dan tidak boleh bagi laki-laki muslim yang lemah imannya. ${ }^{52}$

Kepercayaan kepada kaidah ushul pada masa mutaakhir telah memberikan pengaruh terhadap cabang-cabang paham keagamaan. Dalam masalah pernikahan dengan wanita ahlul kitab, Muhammadiyah telah menggunakan kaidah ushul (saddu al zari'at) yang kemudian sampai pada kesimpulan bahwa pernikahan beda agama tidak boleh secara mutlak, ${ }^{53}$ wajib dihindari. ${ }^{54}$

Jika ditelaah lebih dalam, Muhammadiyah mengalami kesulitan dalam menggunakan kaidah ushul secara lugas. Kepercayaan akan keabsahan nash dalam makna harfiah dan penggunaan kaidah ushul sebagai penjabaran nash, menyebabkan lahirnya keraguan dalam masalah pernikahan dengan ahlul kitab ini. Kepercayaan bahwa nash secara harfiah harus diikuti dan penerapan kaidah ushul ini kemudian melahirkan hukum yang mengambang, yaitu tidak membolehkan pernikahan beda agama secara mutlak, dalam perspektif syari'ah bisa

51 Lihat Abdul Munir Mulkhan, Jawaban Kiyai Muhammadiyah, hlm. 177-179.

${ }^{52}$ Lihat Hamka, Tafsir Al A₹har, juгu’ VI (Jakarta: Pustaka Panjimas, 1989), hlm. 143-145.

${ }^{53}$ Lihat Majelis Tarjih dan Pengembangan Pemikiran Islam, Tafsir Tematik, hlm.219.

54 Tim Majelis Tarjih, Tanya Jawab, 1, hlm. 187. 
Al-Fikra: Jurnal Ilmiah Keislaman, Vol. 8, No. 2, Juli-Desember 2009

dibenarkan. ${ }^{55}$ Laki-laki mukmin boleh kawin dengan wanita ahli kitab, ${ }^{56}$ sebagaimana dijelaskan di dalam surat al Maidah ayat 5, namun lebih baik dihindari. ${ }^{57}$

Keraguan seperti ini menunjukkan bahwa penempatan teks nash sebagai dasar hukum sangat dominan. Namun dalam masalah nikah beda agama Muhammadiyah menghadapi berbagai hambatan dalam menerima teks nash secara harfiah, adanya teks yang menghalalkan menikahi wanita ahlul kitab dan larangan menikahi wanita musyrik, gambaran negatif terhadap ahlul kitab yang termuat di dalam berbagai ayat Al-Quran dan kondisi masyarakat muslim dam non-muslim saat ini, menjadi konflik dalam menetapkan hukum. Menurut Fathurrahman Djamil, Muhammadiyah mempertahankan kepercayaan dualistik ini dengan menyebut bahwa larangan menikahi wanita ahli kitab tersebut sebagai haram lisaddi al zari'at. ${ }^{58}$ Karena pada dasarnya pernikahan tersebut dibolehkan, larangan hanyalah karena mencegah terjadinya hal yang dilarang yaitu pindah agama atau kefasadan lainnya, kemaslahatan pada suatu saat, harus "didahulukan" daripada nash. ${ }^{59}$

Al-Quran dan Hadis sebagai dasar mutlak dalam berhukum sebagaimana ketetapan mukhtamar tahun 1954-1955, dalam kasus pernikahan beda agama penerapannya dirumuskan dengan menggunakan kaidah ushul, sehingga melahirkan implementasi hukum yang dipandang sesuai dengan keadaan masyarakat saat ini dan dipandang tidak bertentangan dengan maqashidu $n$ nash.

Dalam kasus kepemimpinan wanita, Muhammadiyah tidak menempatkan nash (hadis) sebagai dasar mutlak dalam menetapkan hukum. Menurut kepercayaan Muhammadiyah, wanita dibolehkan menjadi hakim ataupun pemimpin masyarakat. ${ }^{60}$ Majelis mengemukakan ada hadis yang menerangkan: "Tak akan berhasil

55 Majelis Tarjih dan Pengembangan Pemikiran Islam, Tafsir Tematik, hlm.219.

56 Tim Majelis Tarjih, Tanya Jawab, 4, hlm. 206

57 Lihat ibid., hlm. 207.

58 Fathurrahman Djamil, Metode Ijtihad Majelis Tarjih, hlm. 147.

59 Ibid.

${ }^{60}$ Lihat Majelis Tarjih, Adabul Mar'ah fil Islam, hlm. 57.
Zuriatul Khairi, Teologi Muhammadiyah ...

golongan orang yang menyerahkan kekuasaan urusan mereka pada seorang wanita". Menurut Majelis hadis ini harus ditafsirkan sebagai gambaran keadaan masa lalu ketika kondisi wanita tidak memungkinkan untuk diserahi mengurusi urusan kekuasaan. Keadaan itu berbeda dengan masa sekarang, dengan terbukanya kesempat bagi wanita untuk memiliki kemampuan setara dengan laki-laki, telah menampilkan banyak wanita dengan kemampuan yang tidak diragukan lagi. Majelis mengemukakan: "pada zaman sekarang rasanya tak tepat lagi dipersoalkan: Bolehkah wanita menjadi Hakim?”.61

\section{Kesimpulan}

Berdasarkan uraian dan analisa yang telah dikemukakan, disimpulkan bahwa perkembangan konsep kepercayaan Muhammadiyah tentang nash sebagai sumber yang harus didahulukan, yang kemudian juga mempercayai keabsahan penafsiran dan kaidah ushul fikih, mempengaruhi keputusan-keputusan hukum yang ditetapkannya. Dengan demikian dapat dikatakan bahwa produk fikih tidak dapat dilepaskan dari konsep kepercayaan (teologi) terhadap sumber pemahaman itu sendiri.

\section{Bibliografi}

Abdurrahman, Asjmuni, Manhaj Tarjih Muhammadiyah Metodologi dan Aplikasi, (Yogyakarta: Pustaka Pelajar, 2004).

Aziz, Rs. Abdul, Konsepsi Ahlussunnah wal-jamaah dalam Bidang Aqidah dan Syari'ah, (Pekalongan: Bahagia, 1990).

Basyir, Ahmad Azhar, Pendidikan Agama Islam I (Aqidab), (Yogyakarta: Perpustakaan FH UII, 1995).

Dahlan, Abdul Aziz, "Akidah" dalam Ensiklopedi Tematis Dunia Islam, vol. 3.

Djamil, Fathurrahman, Metode Ijtihad Majelis Tarjih Mubammadiyah, (Jakarta: Logos, 1995). 
Al-Fikra: Jurnal Ilmiah Keislaman, Vol. 8, No. 2, Juli-Desember 2009

Gunawan, Wawan dan Inayati, Evie Shofia (eds.), Wacana Fiqh Perempuan Dalam Perspektif Mubammadiyah, MTPPI PP Muhammadiyah Yogyakarta dan UHAMKA (Jakarta: UHAMKA, 2005).

Hamka, Tafsir Al Az̧ar, juzu’ VI, (Jakarta: Pustaka Panjimas, 1989).

Ilyas, Hamim, "Rekonstruksi Figh Perempuan" dalam Wawan Gunawan, dan Evie Shofia Inayati (eds.), Wacana Fiqh Perempuan Dalam Perspektif Muhammadiyah, MTPPI PP Muhammadiyah Yogyakarta dan UHAMKA (Jakarta: UHAMKA, 2005).

Ilyas, Yunahar, Kuliah Aqidah Islam, (Yogyakarta: LPPI Muhammadiyah, 1993).

Tafsir Tematis Cakrawala Al Quran, (Yogyakarta: Suara Muhammadiyah, 2003).

Jamil, M. Muhsin, Membongkar Mitos Menegakkan Nalar, pergulatan Islam Liberal versus Islam Literal, (Yogyakarta: Pustaka Pelajar, 2005).

Machasin, Islam Teologi Aplikatif, Yogyakarta: Pustaka Alief, 2003.

Majelis Tarjih dan Pengembangan Pemikiran Islam PP Muhammadiyah, Tafsir Tematik Al Quran Tentang Hubungan Sosial Antarumat Beragama, (Yogyakarta: Pustaka Suara Muhammadiyah, 2000).

Majelis Tarjih Pimpinan Pusat Muhammadiyah, Adabul Mar'ab fil Islam, (Yogyakarta: Majelis Tarjih Pimpinan Pusat Muhammadiyah, t.th).

Mas, Subhan, Muhammadiyah Pintu Gerbang Protestanisme Islam, Sebuah Presisi Modernitas, (Mojokerto: CV. Al Hikmah, 2005).

Maududi, Abul A'la, Dasar-dasar Iman, terj. Afif Mohammad dan Chatib Saifullah, (Bandung: Pustaka, 2000).
Zuriatul Khairi, Teologi Muhammadiyah ...

Mulkhan, Abdul Munir, Jawaban Kyai Muhammadiyah Mengurai Jawaban Pak AR Dan 274 Permasalahan dalam Islam, (Yogyakarta: Kreasi Wacana, 2004).

Masalab-masalah Teologi dan Figh dalam Tarjiih Muhammadiyah, Yogyakarta: Roykhan, 2005.

Nasution, Harun, Akal dan Wabyu dalam Islam, (Jakarta: UI Press, 1986).

Teologi Islam sejarah aliran-aliran dan analisa perbandingan, (Jakarta: UI Press, 2002).

Pimpinan Pusat Muhammadiyah, Himpunan Putusan Majelis Tarjib Muhammadiyah, (Yogyakarta: PP Muhammadiyah, t.th).

Praja, Juhaya S., Filsafat Hukum Islam, (Bandung: LPPM-UIB, 1995).

Rais, M. Amin, Taubid Sosial: Formula Menggempur Kesenjangan, (Bandung: Mizan, 1998).

Sukardja, Ahmad, Piagam Madinah dan Undang-undang Dasar 1945 Kajian Perbandingan tentang Dasar Hidup Bersama dalam Masyarakat yang Majemuk, (Jakarta: UI Press, 1995).

"Pendahuluan: Akidah Sebagai Dasar Pandangan Hidup", Ensiklopedi Tematis Dunia Islam, vol 3, halaman 1-7.

Surur, Bahrus, Teologi Amal Saleh: Membongkar Nalar Kalam Muhammadiyah Kontemporer, (Surabaya: LPAM, 2005).

Tim Majelis Tarjih Muhammadiyah, Tanya Jawab Agama, 1, (Yogyakarta: Suara Muhammadiyah, 2003).

Tanya Jawab Agama, 2, (Yogyakarta: Suara Muhammadiyah, 2003).

Tanya Jawab Agama, 3, (Yogyakarta: Suara Muhammadiyah, 2004).

Tanya Jawab Agama, 4, (Yogyakarta: Suara Muhammadiyah, 2003). 